IZA DP No. 5209

The Effect of Early Childhood Developmental Program Attendance on Future School Enrollment and Grade Progression in Rural North India

Gautam Hazarika

Vejoya Viren

September 2010 


\title{
The Effect of Early Childhood Developmental Program Attendance on Future School Enrollment and Grade Progression in Rural North India
}

\author{
Gautam Hazarika \\ University of Texas, Brownsville \\ and IZA \\ Vejoya Viren \\ University of Texas, Brownsville
}

Discussion Paper No. 5209

September 2010

\author{
IZA \\ P.O. Box 7240 \\ 53072 Bonn \\ Germany \\ Phone: +49-228-3894-0 \\ Fax: +49-228-3894-180 \\ E-mail: iza@iza.org
}

Any opinions expressed here are those of the author(s) and not those of IZA. Research published in this series may include views on policy, but the institute itself takes no institutional policy positions.

The Institute for the Study of Labor (IZA) in Bonn is a local and virtual international research center and a place of communication between science, politics and business. IZA is an independent nonprofit organization supported by Deutsche Post Foundation. The center is associated with the University of Bonn and offers a stimulating research environment through its international network, workshops and conferences, data service, project support, research visits and doctoral program. IZA engages in (i) original and internationally competitive research in all fields of labor economics, (ii) development of policy concepts, and (iii) dissemination of research results and concepts to the interested public.

IZA Discussion Papers often represent preliminary work and are circulated to encourage discussion. Citation of such a paper should account for its provisional character. A revised version may be available directly from the author. 
IZA Discussion Paper No. 5209

September 2010

\section{ABSTRACT \\ The Effect of Early Childhood Developmental Program Attendance on Future School Enrollment and Grade Progression in Rural North India}

This paper examines the effect of prior participation in early childhood developmental programs, considered endogenous, upon 7-19 years olds' school enrollment and grade progression in rural North India. It hopes both to extend to less developed countries recent influential research on the long-term benefits of early childhood interventions in the United States, and to make a case for the inclusion of such interventions amongst developing nations' policy initiatives toward expanding schooling. Analysis of data from the World Bank's 1997-98 Survey of Living Conditions in Uttar Pradesh and Bihar yields the findings that early childhood developmental program attendance at ages 0-6 raises the probability of school enrollment among average 7-19 year olds by 31 percentage points, and that this beneficial early experience also significantly hastens students' grade progression.

JEL Classification: $\quad 121,012,015$

Keywords: $\quad$ early childhood development, less developed country, India, schooling

Corresponding author:

Gautam Hazarika

Department of Business Administration

The University of Texas at Brownsville

80 Fort Brown

Brownsville, TX 78520

USA

E-mail: gautam.hazarika@utb.edu 


\section{INTRODUCTION}

This study has two objectives. First, it aims to extend to less developed countries the exciting new burgeoning body of economic research on early childhood development in the United States (e.g., Heckman, 2008). Next, it aims to investigate the efficacy of a somewhat overlooked, by academics and policy makers, means of boosting school attendance and attainment in less developed countries, namely, formal early childhood care and education.

Whilst early childhood development has perennially interested educationists and psychologists, it has only recently piqued the attention of economists. Economists in the United States have begun to view early childhood developmental interventions as cost effective means of redressing rising income inequality. Heckman (2008) observes that "American society is polarizing". Cunha and Heckman (2008) show that factors determined by as early as age 18 , such as family background, drive interpersonal variation in lifetime earnings. It would appear that American adolescents' destinies, though not set in stone, are etched in rapidly hardening cement. That children cannot purchase their family backgrounds, and that parents without means cannot borrow to invest in their young children, lead to market failure ${ }^{1}$ (Cunha, Heckman, Lochner, and Masterov, 2006), remediable by public early childhood developmental interventions. Cunha, Heckman, Lochner, and Masterov (2006) summarize some experimental evidence, gleaned from randomized controlled trials, of the long-term benefits to children from early intervention programs in the United States. Exposure to superior preschool environments may lead to higher achievement test scores, higher grades at school, higher rates of high school graduation, higher rates of employment, better jobs, lower propensities to crime, more healthful lifestyles, lower rates of teen pregnancy, and higher rates of marriage. A recent widely publicized analysis ${ }^{2}$ by Chetty et al. (2010) of data also yielded by an experiment utilizing a randomized protocol indicates that children who learn more in kindergarten, mainly from better teaching, enjoy higher earnings by age 27, are likelier to attend college, likelier to become home owners by age 28 , likelier to save for retirement, and less likely to become single parents. Such studies are yet to be replicated in the developing world ${ }^{3}$, where, it might be argued, the accident of birth has farther reaching consequences.

Economists have long considered schooling a key factor in economic growth and development. Macroeconomists have found a strong positive relation between a nation's rate of economic growth and the educational attainments of its citizenry in cross-country growth regressions (e.g., Barro, 1991), though the

1 in that the existing 'market' for early childhood human capital investment delivers, from society's viewpoint, a suboptimal equilibrium quantity

2 described in the New York Times (Leonhardt, 2010)

3 MIT's Abdul Latif Jameel Poverty Action Lab (J-PAL) has participated in a small number of randomized controlled trials in preschool settings in the developing world in recent years, but the studied children haven't yet been followed into subsequent schooling and beyond. 
direction of causation isn't wholly established ${ }^{4}$ (e.g., Bils and Klenow, 2000). Microeconomists, focused on the private gains from education, have estimated high rates of return to schooling in developing countries (e.g., Psacharopoulos and Patrinos, 2004 ). More educated farmers have been found to be likelier to adopt new 'Green Revolution' technologies (e.g., Foster and Rosenzweig, 1996). Further, parents' education, especially mothers' education, has been seen to improve child health and nutrition, and promote children's schooling (e.g., Schultz, 2002). So it has been common for developing nations to pursue policies to boost school enrollment, attendance, and attainment.

Glewwe and Kremer (2006) summarize the principal obstructions to schooling in developing countries. These are: lack of access to schools, their high cost, their low quality, and, lastly, poor child health. Numerous empirical studies employing experimental, quasi-experimental, and non-experimental-survey data largely confirm that removal of these obstructions stands to substantially expand schooling. Since randomized experiments are now often considered the 'gold standard' in social policy assessment ${ }^{6}$, we dwell below on a few such studies which employ experimental or quasi-experimental data.

Burde and Linden (2010) analyze data generated by an experiment in the random assignment of new primary schools to villages in north-west Afghanistan, to find that the intervention raised enrollment in formal schools by 42 percentage points. Hence, improving access to schools may be a very effective means of raising school enrollment in the developing world.

Schultz (2004), in a study of Mexico's Progresa poverty program, which confers cash grants on parents provided their children attend school, conditional cash transfers which may be viewed as lowering the cost of schooling, finds that the Program raised school enrollment in grades 1 through 8 by $3.4 \%$. These Progresa data are experimental in that they pertain to a subset of eligible communities divided in random fashion into a treatment group and a control group. Evens, Kremer, and Ngatia (2009) analyze experimental data yielded by a randomized controlled trial in Kenya which awarded children school uniforms by lottery. The cost of schooling of lottery winners may be considered reduced. It is found that school absenteeism among all winners of uniforms fell by $44 \%$ on average, with a steeper reduction on average, $62 \%$, in absenteeism among winners who didn't previously own a uniform. Hence, reducing the monetary cost of schooling in less developed countries may significantly raise school enrollment and attendance.

Case and Deaton (1999) examine the effect of the quality of schools in South Africa upon children's educational outcomes. It is significant that the data studied by these authors date to 1993, a year before the end of apartheid, when blacks, denied political representation, did not control funding for their children's schools.

4 Instead growth may raise schooling. e.g., growth, even if it is skill-neutral, may increase demand for schooling by raising its effective rate of return, as students giving up current earnings to attend school stand to earn larger sums, owing to economic growth, upon leaving school (Bils and Klenow, 2000). Growth, yielding resources for the expansion of national schooling infrastructure, may even raise the supply of schools.

5 The mean private rate of return to schooling in low income countries is about $11 \%$.

6 though this new eminence accorded them has been questioned (e.g., Deaton, 2009). 
Further, internal black migration was then strictly controlled, ruling out the migration of families to localities with better schools. So, the assignment of black children to schools of varying quality may be considered random, that is, determined within a natural experiment. The authors discover that a lowering of the pupilteacher ratio, their primary measure of school quality, in black schools from 40 to 20 would have added 0.75 years to grade attainment by age 10 and 1.5 years by age 15 . There is a modicum of evidence, therefore, that raising school quality improves educational outcomes in less developed countries ${ }^{7}$.

Finally, Miguel and Kremer (2004), in an analysis of data generated by a randomized controlled trial in Kenya, conclude that initiatives to improve children's health are a potent means of raising school attendance. The experiment introduced a mass de-worming treatment in schools by random assignment in that some schools were randomly chosen to receive the treatment earlier than others. This simple and inexpensive health initiative is found to reduce school absenteeism by as much as $25 \%$, with untreated children in treatment schools benefiting as well from the positive externality of a lower rate of inter-pupil infection.

It is notable that this voluminous body of research devoted to uncovering the effective means of promoting schooling in the developing world makes no mention of one potentially very effectual means, namely, early childhood developmental interventions. This is a glaring omission given the highly publicized long-term benefits of early childhood interventions in the United States, an established theoretical literature in education and psychology fully predictive of these benefits, and the intriguing sizeable positive correlation between low and lower-middle income nations' preschool enrollment rates and their primary school enrollment rates in data from the UNESCO Institute for Statistics ${ }^{8}$. To be fair, development economists have been hampered by a paucity of data. It isn't common for survey data from less developed countries to inform of children's participation in preschool programs, simply because this is rare, especially amongst the poor: data from the UNESCO Institute for Statistics reveal that the mean gross preschool enrollment rate ${ }^{9}$ in low income countries was merely about $14 \%$ in 2007. Experimental data are scarce as well since there have been but few randomized controlled trials in preschool settings in developing countries, all of them recent enough as to rule out long-term assessments.

This study aims to stop this gap in the literature by uncovering evidence of a strong beneficial effect of children's participation in early childhood development programs upon their future schooling in a developing country. It hopes, thereby, to build a case for the inclusion of early childhood interventions amongst developing nations' policy initiatives toward expanding schooling. The data studied, from India, are well suited to this purpose since India is rare among less developed countries in having a 35 year old nation-wide network of public

7 On the other hand, literature surveys by Hanushek $(1986,1995)$ find but a tenuous link between school quality as measured by expended resources, and student outcomes.

8 The estimated regression of 2004-08 average primary enrollment rates in low and lower-middle income countries against these nations' 2004-08 average preschool enrollment rates is primary enrollment rate $=72.9+0.29 \times$ preprimary enrollment rate, the regression's $\mathrm{R}^{2}$ and slope-coefficient t-ratio being, respectively, 0.22 and 4.13 .

9 preschool enrollment as a percentage of all preschool age children 
early childhood developmental facilities called Anganwadi ${ }^{10}$ Centers (AWCs), established as part of the Government of India's Integrated Child Development Services (ICDS) Program. It is creditable that the Government of India has long considered early childhood care and education vital to its efforts at universalizing primary education ${ }^{11}$. Our analysis reveals that the average $7-19$ year old rural North Indian is 31 percentage points likelier to be currently enrolled in school as a result of having previously participated in an early childhood developmental program, whether in an Anganwadi Center, an analogous facility run by a nongovernmental organization ${ }^{12}$, or a preschool classroom ${ }^{13}$. Further, of those presently enrolled, children or youth who participated in early childhood developmental programs are found to have enjoyed faster age-normed grade progression, due presumably to more timely admission to primary school as well as lower rates of grade repetition.

The remainder of this paper is organized as follows. Section 2 draws on a vast literature in neurobiology, nutrition, and psychology to explain the pivotal nature of early childhood. Section 3 describes our empirical methodology. Section 4 summarizes the salient features of the Integrated Child Development Services (ICDS) Program, the cornerstone of India's public policy in relation to young children. Section 5 describes the utilized data and our empirical findings, with section 6 offering a brief conclusion.

\section{THE PIVOTAL NATURE OF EARLY CHILDHOOD}

It is well understood that early childhood is a critical period in human development. Early childhood experiences are capable of leaving indelible marks upon abilities and personality. Abilities are usually taken to mean cognitive abilities, such as intelligence as measured by an IQ test. There is no doubt cognitive abilities are important determinants of life success. However, it is now realized that personality traits like self-regulation, motivation, and sociability have significant bearing on life outcomes as well. Indeed, Heckman, Stixrud, and Urzua (2006) find that such 'noncognitive abilities' are often as strongly correlated with schooling, labor market outcomes, and social (mis)behavior as cognitive abilities ${ }^{14}$.

Early childhood is a critical period in the development of cognitive and noncognitive abilities because the requisite wiring of neural circuitry largely occurs at this time. Early life experiences strongly shape this wiring both because neural circuitry is highly plastic at this stage, and because patterns of neural connections are

10 The Hindi word anganwadi means 'courtyard garden'.

11 In 2005, 34.2\% of Indian children enrolled in the first grade of primary school were not expected to complete their primary education.

12 These include urban Balwadi (kindergarten) Centers run by the NGO Pratham. Urban India is relatively underserved by the Government's ICDS Program.

13 According to India's National Institute of Educational Planning and Administration (NIEPA), $14.27 \%$ of public primary schools contained preschool sections in 2003.

14 For example, noncognitive skills have approximately the same positive effect on wages as cognitive skills, with noncognitive skills exerting a stronger salubrious effect on employment propensities than cognitive skills. 
more easily formed when there aren't any established patterns to begin with, that is, when the slate is blank (Knudsen, Heckman, Cameron, and Shonkoff, 2006). For example, when a young child has worse vision in one eye than in the other, that is, is more reliant on one of her eyes, neural connections from it to her brain proliferate whereas connections from the eye less relied on wither away, and this process is irreversible once a sensitive period in early childhood is past.

Similarly, children unexposed to language during a sensitive period of early childhood may become largely incapable of language because of attrition in their brains' neural circuitry responsible for language acquisition. So called 'feral children', of whom there are many historical examples ${ }^{15}$ (Benzaquen, 2006), may have suffered precisely this form of neural atrophy, for no rescued feral child ever learnt to speak fluently. It is curious that these linguistically challenged feral children were also severely cognitively challenged. It is possible that they were abandoned by their families because they were cognitively challenged, but this could not have been true of feral children who, when rescued, were far too young ${ }^{16}$ to have been sensibly assessed as mentally impaired. In light of the highly influential human developmental theories of the Soviet psychologist Lev Vygotsky $^{17}$, it is likelier that these children's cognitive impairment was tied to their lack of language. Vygotsky held that language, paramount of mental tools, played a central role in the acquisition of other mental tools. By Vygotskian theory, language makes thought possible, that is, thoughts come into existence through words. Indeed, Vygotsky held that words play a central role in the growth of consciousness. Thus, acquisition of the cognitive skill of language, largely impossible outside a fairly narrow window in childhood, may open doors to higher cognitive functioning. In addition, language may influence the development of noncognitive skills as well. For example, young children use 'private speech' or self-talk as a tool of self-regulation or self-control (Leong and Bodrova, 2006), an important noncognitive skill linked with future success ${ }^{18}$.

There is evidence that other personality traits, like reactivity to stress, are also closely formed in early childhood. For example, biological experiments have found that rat pups reared in the first week of their lives by a relatively indifferent dam, not necessarily their mother ${ }^{19}$, grew up to be more reactive to stress, more anxious, more fearful, and less adventurous than pups reared by a more solicitous dam. These permanent changes in

15 These were children who'd ostensibly been brought up by wild animals after being abandoned in their infancy. Victor of Aveyron was one such child, finally rescued in 1800 in southern France.

16 For example, the feral child Amala was only 18 months old when rescued near Midnapore, eastern India, in 1920.

$171896-1934$

18 There is a considerable literature, to which belongs Stanford psychologist Walter Mischel's famous 'Marshmallow Experiment', supportive of a strong positive relation between patience in young children, a type of self-regulation, and their future cognitive and social competence (e.g., Mischel, Shoda, and Rodriguez, 1989). In the Marshmallow Experiment, 4-year olds in a laboratory school at Stanford University in the late 1960s were each presented with a marshmallow and told that if they waited 20 minutes before eating it, they would receive another. It was observed that some children were able to wait longer than others. The researchers then followed these children into adolescence to discover striking patterns.

19 since the experiments attempted cross-fostering in order to sever genetic links between the pups and their caregivers 
temperament seem rooted in epigenetic ${ }^{20}$ changes wrought by the excessive release of stress hormones in early life $^{21}$. Their cause being epigenetic, such modification to temperament may, sadly, be passed on to future generations $^{22}$. It is believed that this model is applicable to humans as well (e.g., Lords, 2009).

There can be no starker or more poignant demonstration of the critical nature of early childhood than the grim lifelong consequences of the in utero and early childhood malnutrition common in less developed countries $^{23}$. Malnutrition in utero and during the first two or three years of life may irreversibly stunt physiques, reduce cognitive development so as to permanently lower IQ, decrease attention and focus, hinder learning, impede educational attainment, and lead to behavioral difficulties and poor social skills (Martorell, 1999).

In sum, it is clear that early childhood is a momentous phase in human development. A young child's experiences may well set the tone for the rest of her life. Moreover, her experiences may also, via epigenetic transmission, affect her immediate future generations.

\section{EMPIRICAL MODELS AND ESTIMATION}

This study aims to gauge the effect of rural Northern Indian children's participation in early childhood developmental programs upon their subsequent school attendance and, given attendance, their grade progression. School attendance in measured in binary fashion, and grade progression continuously as 'schooling for age', or $S A G E^{24}$, defined as

$$
\text { [ grade presently attending } \div(\text { age }-6)] \times 100 \text {. }
$$

The effect of participation in early childhood developmental programs, the 'treatment' in this instance, upon future school attendance may be estimated via the equation

$$
\text { attend }_{i}^{*}=X_{i}^{\prime} a_{1}+a_{2} . E C D_{i}+e_{1 i},
$$

where attend $_{i} *$ is a latent variable underlying its observed binary counterpart, attend $d_{i}$, an indicator of whether child or youth $i, 7$ to 19 years old, is presently attending an educational institution, the $X_{i}$ are personal, household, and community characteristics with bearing on school attendance, $E C D_{i}$ is an indicator of whether child or youth $i$ participated in an early childhood developmental program between the ages of 0 and 6 , and $e_{1 i}$, the error term, denotes unobserved influences upon school attendance. (1) may not simply be estimated by, e.g., probit ML because it is probable that participants in early childhood developmental programs are different from

20 Epigenetic changes are changes in gene expression (the 'turning on' or 'turning off' of genes) caused by mechanisms other than changes in the underlying DNA sequence. Such changes are inheritable, at least within proximal generations.

21 The brains of the more fearful pups had far fewer glucocorticoid receptors, responsible for dampening down the release of stress hormones, owing to these pups' early childhood stress 'turning off' certain genes responsible for the growth of these receptors.

22 It has been found, for example, that post-traumatic stress disorder in Holocaust survivors is a risk factor in the development of this disease in their adult offspring (Bierer, 2008).

23 For example, $41 \%$ of $0-5$ year children in South Asia are malnourished in the sense of being underweight.

24 used, for example, by Ray and Lancaster (2005) 
non-participants in unobserved ways. For example, parents with strong taste for educated children may both enroll them in an early childhood developmental program and insist that they continue formal schooling long afterwards. Alternatively, certain early childhood developmental programs target 'at risk' children from disadvantaged families unlikely to foster educational attainment. If the unobserved aspects of such family attributes were subsumed within the error term $e_{1}$, estimates of the coefficient $a_{2}$ would be inconsistent. It would be necessary, then, to instrument the regressor $E C D$. A plausible instrument is geographical access to an early childhood developmental program, for example, an indicator of the local presence of such a program. Hence, (1) must be estimated together with a second equation such as

$$
E C D_{i}{ }^{*}=X_{i}{ }^{\prime} b_{1}+b_{2} . \text { access }_{i}+u_{1 i},
$$

where $E C D_{i} *$ is the latent variable underlying the binary $E C D_{i}$, access $_{i}$ is an indicator, plausibly exogenous, of whether child or youth $i$ 's village is home to an early childhood developmental program, and $u_{l i}$, the error term, denotes unobserved influences upon early childhood developmental program participation. Note that (1) and (2) constitute a recursive simultaneous equation system with binary key variables, corresponding to Maddala's and Lee's (1976) Model 1. Assuming that the errors $e_{l}$ and $u_{l}$ are bivariate-normally distributed, the equations may be jointly estimated by bivariate probit ML "as if there were no simultaneity problem” (Greene, 1998).

Similarly, the effect of participation in early childhood developmental programs upon grade progression in school, conditional on enrollment, may be estimated via the equation

$$
S A G E_{i}=X_{i}^{\prime} a_{3}+a_{4} \cdot E C D_{i}+e_{2 i},
$$

where, as described, $S A G E_{i}$ is a continuous variable measuring the pace of enrolled child or youth $i$ 's grade progression, the $X_{i}$, personal, household, and community characteristics with bearing on school attendance, are plausible correlates of grade progression as well, $E C D_{i}$ is, as before, an indicator of whether child or youth $i$ participated in an early childhood developmental program between the ages of 0 and 6 , and $e_{2 i}$, the error term, denotes unobserved influences upon grade progression. (3) may not simply be estimated by OLS since it is probable that participation in an early childhood developmental program is endogenous. For example, parents with strong taste for educated children may both enroll them in an early childhood developmental program and, later, ensure that they don't lag in school. If unobserved aspects of such parental taste were subsumed within the error term $e_{2}$, OLS estimates of the coefficient $a_{4}$ would be biased. So it would be necessary, again, to instrument the regressor $E C D$. In other words, (3) as well must be estimated together with a second equation such as (2). Note that (3) and (2) constitute a recursive simultaneous equation system with one of its key variables continuous and the other binary, corresponding to Maddala's and Lee's (1976) Model 2, and may be estimated by maximum-likelihood. 


\section{THE INTEGRATED CHILD DEVELOPMENT SERVICES PROGRAM}

Launched by the Government of India on October 2, 1975, the Integrated Child Development Services (ICDS) Program takes a holistic view of early childhood care and education. Its Anganwadi Centers provide $0-6$ year old children as well as pregnant women and lactating mothers with supplemental nutrition, preventive health care, and medical referrals. They also supply $3-6$ year olds with a play-centered preschool education, and pregnant woman and lactating mothers with health and nutrition education. While centrally sponsored, the ICDS Program is implemented by the governments of India's states and union territories.

An Anganwadi Center is usually staffed by two women: a worker, normally trained for about 4 months in health, nutrition, and child care, and her helper. The pair are invariably local and underprivileged, and their work no doubt empowers them. Delivery of the more skill-intensive of the health care services of an Anganwadi Center, such as immunization, growth monitoring, and medical referral isn't left to its rudimentarily trained worker. Instead, these services are provided by the local public health administration.

Originally, only individuals from families gauged as living below the poverty line were eligible for the full range of the ICDS Program's services. However, in 2001, India's Supreme Court ruled that it ought to be extended to all 0 - 6 year old children, adolescent girls, pregnant woman, and lactating mothers. By the end of March 2009, there were about 1.04 million Anganwadi Centers providing supplemental nutrition to 87.34 million women and children, and preschool education to 34.06 million children, making the ICDS Program the world's largest such endeavor.

Anganwadi Centers have tended to focus on their health and nutrition services, that is, have been somewhat neglectful of their preschool function. That the ICDS Program has inclined to favor rural India despite great need for its services in urban India may be considered another of its shortcomings. The Program has been considerably underfunded. Further, Anganwadi Centers have tended not to take the beneficial participatory approach of closely involving their local communities.

It may be seen that there are many similarities between India's ICDS Program and the United States' Head Start Program, which preceded the former by some 10 years. For example, both have catered to underprivileged or 'at risk' children. Both have closely involved the children's families. Both have taken a multidisciplinary approach to children, combining medicine, public health, nutrition, child development, and early childhood education. Finally, both have tended to employ local underprivileged women who have, as a result, been usefully empowered.

\section{DATA AND EMPIRICAL FINDINGS}

The empirical models described in section 3 above are fitted to data from the 1997-98 Survey of Living 
Conditions in Uttar Pradesh and Bihar. The survey is part of the Living Standards Measurement Survey (LSMS) series of the World Bank. It covered 2,250 households drawn from 120 villages in 25 districts of rural southern and eastern Uttar Pradesh and rural northern and central Bihar. With nearly 176 million residents, Uttar Pradesh is India's most populous state. Bihar, with a population of nearly 83 million, is India's third-most populous state 25. Both states are ranked amongst the lowest in the Indian Union by almost all indicators of poverty and socioeconomic development.

The Survey ascertained whether $6-19$ year olds in the sampled households had ever attended an early childhood developmental program. Their present school enrollment status was also established ${ }^{26}$. The grade levels of the children presently attending school was confirmed. The Survey noted the age and gender of each child or youth, and collated a rich variety of household and community characteristics. Since participation in early childhood developmental programs typically spans the ages of $0-6$, we consider the ages of $7-19$ to be children's post-preschool years so as to effect an empirically convenient separation of these two phases in children's lives. We then examine the effect on school attendance and grade progression among $7-19$ year olds of their participation in an early childhood developmental program when they were $0-6$ years old.

Our statistical analysis is based on a sample of 3,669 7 - 19 year olds, of whom 2,340 are between the ages of 7 and 12, and 1,329 are 13 - 19 year olds. Table 1 presents the sample mean values of all utilized variables. $60.9 \%$ of these $7-19$ year olds were enrolled in school at the time of the survey. $58 \%$ of the sample was male. These $7-19$ year olds' average age was about eleven and a half. $10 \%$ of them were muslim ${ }^{27}$. The average child or youth resided in a household of about 8 members. Her household held about 2.6 acreas of land. She lived about half a kilometer away from the closest primary school, about 2.7 kilometers away from the closest middle school, and at a distance of about 4.9 kilometers from the nearest secondary school.

Approximately $38 \%$ of the sample lived in villages with access to early childhood developmental facilities ${ }^{28}$, though, curiously, only about $9 \%$ ever availed of them ${ }^{29}$. In 1997-98, the years to which these data pertain, only children in households assessed as living below the poverrty line (BPL) were eligible to make full use of Anganwadi Centers. Might this explain the above low rate of utilization of early childhood developmental facilities? It is found, however, that only a marginally higher proportion, 9.6\%, of children and youth in BPL households ever benefited from early childhood interventions.

Table 2 presents estimates of (1), arrived at by joint-estimation of (1) and (2) as described in section 3. A 7 - 19 year old's prior participation in an early childhood developmental program is instrumented by an

25 In 2000, the two states were subdivided. Uttaranchal, renamed Uttarakhand, was carved from Uttar Pradesh and Jharkhand from Bihar.

26 A very small number of youth were enrolled in post-secondary institutions.

$2713.4 \%$ of India's population is muslim.

28 About $31 \%$ of the sample lived in villages served by Anganwadi Centers; approximately $8 \%$ lived in villages served by schools offering preschool classes.

29 Of those who did, about $65 \%$ attended regular preschool, about $16 \%$ attended Anganwadi Centers, and approximately $17 \%$ attended facilities run by NGOs. 
indicator of the presence in her village of either an Anganwadi Center or a school offering preschool classes. Estimates of (2), unreported in the interest of brevity, indicate that such local access to early childhood care and education is a highly statistically significant correlate of $7-19$ year olds' prior enrollment in early childhood developmental programs. By the estimates in table 2, boys are significantly likelier than girls to have been enrolled in school at the time of the Survey. The probabability of school enrollment decreases in age. It also decreases in the number of co-resident younger children, perhaps because older children in rural India commonly assist in the caring of their younger siblings at the cost of schooling. The probability of school enrollment increases in family size, presumably because the availability of more persons to shoulder chores reduces the burden of work upon school age household members. A child or youth from a muslim household, or from one whose head is illiterate appears less likely to be enrolled in school. School enrollment seems subject to a wealth effect in that the probability of enrollment increases both in household landholding and household undearned income from remittances. School enrollment appears deterred by distances to the closest middle and secondary schools, and the monetary cost of schooling. Children or youth in Bihar are less likely to have been enrolled in school at the time of the Survey than their peers in Uttar Pradesh.

These estimates amply indicate that $7-19$ year olds who participated in early childhood devlopmental programs when they were $0-6$ years old are significanty likelier to have been enrolled in school at the time of the Survey. Indeed, the average $7-19$ year old is 31 percentage points likelier to be enrolled in school as a result of having previously participated in an early childhood developmental program. It is clear that this effect persists into adolescence, seeing that even $12-19$ year old beneficiaries of early childhood interventions are much liklier to be enrolled in school.

Table 3 presents estimates of (3), arrived at by joint-estimation of (3) and (2) as described in section 3. A student's previous participation in an early childhood developmental program is instrumented by an indicator of the presence in her village of either an Anganwadi Center or a school offering preschool classes. It is found that boys enjoy more rapid grade progression than girls, and that grade progression slows with age. A student from a muslim household, or from one whose head is illiterate is likelier to be attending a lower grade than is ageappropriate. Household landholdings seem to hasten grade progression, whereas this is slowed by household non-farm enterprises. Perhaps students must tend to their households' non-farm enterprises, such as village shops, at the cost of their studies, since it is plausible that the nature of such enterprises invites petty pilferage by hired hands. The monetary costs of primary schooling seem to raise students' pace of grade progression. Perhaps high school costs serve to winnow out less able or motivated students. Students in Bihar, and in villages in which all agricultural land is irrigated, appear to enjoy more rapid grade progression. Finally, the estimates indicate that $7-19$ year old students who previously participated in an early childhood developmental program progress through grade levels in a distinctly speedier manner than students without such beneficial early experience. 


\section{CONCLUSION}

In sum, our analysis reveals that rural North Indian 7 - 19 year olds with prior experience of preschool care and education are significantly likelier to be enrolled in school. Further, students with such beneficent early experience enjoy faster age-normed grade progression. We believe these findings make a strong case for the inclusion of early childhood interventions amongst developing nations' policy tools for the expansion of schooling.

That this study extends to less developed nations, recent influential research upon the many benefits of early childhood interventions in the United States, is its other achievement. Its findings will, we hope, remind educationists and policy makers in less developed countries, as well as development economists, of the pivotal nature of early childhood.

\section{REFERENCES}

Barro, R., 1991, "Economic Growth in a Cross-Section of Countries", Quarterly Journal of Economics, 106(2), pp. 407-43.

Benzaquen, A. S., 2006, Encounters with Wild Children: Temptations and Disappointment in the Study of Human Nature, Montreal \& Kingston: McGill-Queen's University Press.

Bierer, Y. R., 2008, “Transgenerational Transmission of Cortisol and PTSD Risk”, Progress in Brain Research, 167, pp. 121-35.

Bils, M and P. Klenow, 2000, “Does Schooling Cause Growth?”, American Economic Review, 90(5), pp. 116083.

Bobonis, J., E. Miguel, and C. P. Sharma, 2004, “Iron Deficiency Anemia and School Participation”, Paper No. 7, Abdul Latif Jameel Poverty Action Lab, Massachusetts Institute of Technology (http://www.povertyactionlab.org/sites/default/files/publications/9_Miguel_Iron_Deficiency_and_Partici pation.pdf).

Burde, D. and L. L. Linden, 2010, “The Effect of Village Schools: Evidence from a RCT in Afghanistan”, Academic Publication, Abdul Latif Jameel Poverty Action Lab (http://www.povertyactionlab.org/sites/default/files/publications/Afghanistan\%202010-03-20.pdf).

Case, A. and A. Deaton, 1999, "School Inputs and Educational Outcomes in South Africa", Quarterly Journal of Economics, 114(3), pp. 1047-85.

Chetty, R., J. N. Friedman, N. Hilger, E. Saez, D. Schanzenbach, and D. Yagan, 2010, "How Does Your Kindergarten Classroom Affect Your Earnings? Evidence from Project Star”, unpublished 
manuscript, Harvard University (http://obs.rc.fas.harvard.edu/chetty/STAR_slides.pdf).

Cunha, F. and J. J. Heckman, 2008, “A New Framework for the Analysis of Inequality”, Macroeconomic Dynamics, 12(S2), pp. 315-54.

Cunha, F. and J. J. Heckman, 2010, “Investing in Our Young People”, IZA Discussion Paper 5050, Bonn: Institute for the Study of Labor.

Cunha, F., J. J. Heckman, L. J. Lochner, and D. V. Masterov, 2006, "Interpreting the Evidence on Life Cycle Skill Formation", in E. A. Hanushek and F. Welch, eds., Handbook of the Economics of Education, Vol. 1, Chapter 12, pp. 697 - 812, Amsterdam: North-Holland.

Deaton, A., 2009, "Instruments of Development: Randomization in the Tropics, and the Search for the Elusive Keys to Economic Development”, NBER Working Paper 14690, Cambridge, MA: National Bureau of Economic Research (http://www.nber.org/papers/w14690.pdf).

Evans, D., M. Kremer, and M. Ngatia, 2009, “The Impact of Distributing School Uniforms on Children's Education in Kenya”, Academic Publication, Abdul Latif Jameel Poverty Action Lab (http://www.povertyactionlab.org/sites/default/files/publications/169\%20new\%20paper, \%20 november\%202009.pdf).

Glewwe, P. and M. Kremer, 2006, "Schools, Teachers, and Educational Outcomes in Developing Countries", in E. A. Hanushek and F. Welch, eds., Handbook of the Economics of Education, Vol. 2, Chapter 16, pp. 946 - 1012, Amsterdam: North-Holland.

Greene, W., 1999, “Gender Economics at Liberal Arts Colleges: Further Results”, Journal of Economic Education, Vol. 29, No. 4, pp. 291-300.

Hanushek, E., 1986, "The Economics of Schooling: Production and Efficiency in Public Schools", Journal of Economic Literature, 24(3), pp. 1141-77.

Hanushek, E., 1995, “Interpreting Recent Research on Schooling in Developing Countries”, World Bank Research Observer, 10(2), pp. 227-46.

Heckman, J. J., 2008, “Schools, Skills, and Synapses”, Economic Inquiry, 46(3), pp. 289-324.

Heckman, J. J., J. Stixrud, and S. Urzua, 2006, “The Effects of Cognitive and Noncognitive Abilities on Labor Market Outcomes and Social Behavior", Journal of Labor Economics, 24(3), pp. 411-82.

Knudsen, E. I., J. J. Heckman, J. Cameron, and J. P. Shonkoff, 2006, "Economic, Neurobiological, and Behavioral Perspectives on Building America's Future Workforce", Proceedings of the National Academy of Sciences, 103(7), pp. 10155-62.

Miguel, E. and M. Kremer, 2004, "Worms: Identifying Impacts on Education and Health in the Presence of Externalities", Econometrica, 72(1), pp. 159-217.

Leong, D. J. and E. Bodrova, 2006, “Developing Self-Regulation: The Vygotskian View”, Academic Exchange Quarterly, December 22. 
Leonhardt, D., 2010, “The Case for \$320,000 Kindergarten Teachers”, The New York Times, July 27 (http://www.nytimes.com/2010/07/28/business/economy/28leonhardt.html).

Lords, S., 2009, "Bridging Nature and Nurture: A Look at Epigenetic Effects of Stressful Social Environments on Childhood Development", The University of Toronto Medical Journal, 87(1), pp. 50-52.

Maddala, G. S. and L. F. Lee, 1976, "Recursive Models with Qualitative Endogenous Variables", NBER Chapters, in: Annals of Economic and Social Measurement, Vol. 5, No. 4, pp. 168-188, National Bureau of Economic Research, Inc.

Martorell, R., 1999, "The Nature of Child Malnutrition and its Long-Term Implications", Food and Nutrition Bulletin, 20(3), pp. 288-92.

Mischel, W., Y. Shoda, and M. L. Rodriguez, 1989, "Delay of Gratification in Children”, Science, 244(4907), pp. 933-38.

Psacharopoulos, G. and H. A. Patrinos, 2004, "Returns to Investment in Education: A Further Update", Education Economics, 12(2), pp. 111-34

Ray, R. and G. Lancaster, 2005, 'The Impact of Children's Work on Schooling: Multicountry Evidence', International Labour Review, Vol. 144, No. 2, pp. 189-210.

Schultz, T. P., 2002, "Why Governments Should Spend More to Educate Girls", World Development, 30(2), pp. 207-225.

Schultz, T. P., 2004, "School Subsidies for the Poor: Evaluating the Mexican Progressa Poverty Program", Journal of Development Economics, 74(1), pp. 199-250. 
TABLE 1

Sample Means (Standard Deviations in Parentheses)

\begin{tabular}{|c|c|c|c|c|}
\hline & $\begin{array}{l}7-19 \\
\text { year olds } \\
(n=3669)\end{array}$ & $\begin{array}{l}7-12 \\
\text { year olds } \\
(n=2340)\end{array}$ & $\begin{array}{l}13-19 \\
\text { year olds } \\
(\mathrm{n}=1329)\end{array}$ & $\begin{array}{l}\text { Enrolled } \\
7-19 \\
\text { year olds } \\
(n=2230)\end{array}$ \\
\hline \multicolumn{5}{|l|}{ Dependent Variables } \\
\hline Currently enrolled in school $(=0,1)$ & $\begin{array}{c}0.609 \\
(0.488)\end{array}$ & $\begin{array}{c}0.668 \\
(0.471)\end{array}$ & $\begin{array}{c}0.504 \\
(0.500)\end{array}$ & \\
\hline SAGE (schooling for age) & & & & $\begin{array}{c}99.071 \\
(51.803)\end{array}$ \\
\hline \multicolumn{5}{|l|}{ Child/Youth Attributes } \\
\hline Male $(=0,1)$ & $\begin{array}{c}0.580 \\
(0.494)\end{array}$ & $\begin{array}{c}0.532 \\
(0.499)\end{array}$ & $\begin{array}{c}0.663 \\
(0.473)\end{array}$ & $\begin{array}{c}0.645 \\
(0.479)\end{array}$ \\
\hline Age (years) & $\begin{array}{l}11.541 \\
(3.388)\end{array}$ & $\begin{array}{c}9.353 \\
(1.727)\end{array}$ & $\begin{array}{l}15.392 \\
(1.780)\end{array}$ & $\begin{array}{l}11.064 \\
(3.053)\end{array}$ \\
\hline \multicolumn{5}{|l|}{ Household Attributes } \\
\hline Family size & $\begin{array}{c}8.101 \\
(3.897)\end{array}$ & $\begin{array}{c}8.112 \\
(3.878)\end{array}$ & $\begin{array}{c}8.083 \\
(3.931)\end{array}$ & $\begin{array}{c}8.416 \\
(4.146)\end{array}$ \\
\hline No. of $0-6$ year old children in household & $\begin{array}{c}1.419 \\
(1.407)\end{array}$ & $\begin{array}{c}1.598 \\
(1.379)\end{array}$ & $\begin{array}{c}1.103 \\
(1.401)\end{array}$ & $\begin{array}{c}1.445 \\
(1.467)\end{array}$ \\
\hline Household head is illiterate $(=0,1)$ & $\begin{array}{c}0.470 \\
(0.499)\end{array}$ & $\begin{array}{c}0.495 \\
(0.500)\end{array}$ & $\begin{array}{c}0.425 \\
(0.495)\end{array}$ & $\begin{array}{c}0.358 \\
(0.479)\end{array}$ \\
\hline Household head is female $(=0,1)$ & $\begin{array}{c}0.031 \\
(0.174)\end{array}$ & $\begin{array}{c}0.034 \\
(0.182)\end{array}$ & $\begin{array}{c}0.026 \\
(1.160)\end{array}$ & $\begin{array}{c}0.028 \\
(0.166)\end{array}$ \\
\hline Household's religion is Islam $(=0,1)$ & $\begin{array}{c}0.100 \\
(0.300)\end{array}$ & $\begin{array}{c}0.099 \\
(0.299)\end{array}$ & $\begin{array}{c}0.102 \\
(0.302)\end{array}$ & $\begin{array}{c}0.087 \\
(0.281)\end{array}$ \\
\hline Household's landholding (acres) & $\begin{array}{c}2.571 \\
(5.454)\end{array}$ & $\begin{array}{c}2.263 \\
(4.774)\end{array}$ & $\begin{array}{c}3.113 \\
(6.445)\end{array}$ & $\begin{array}{c}3.082 \\
(6.056)\end{array}$ \\
\hline No. of household non-farm enterprises & $\begin{array}{c}0.518 \\
(0.747)\end{array}$ & $\begin{array}{c}0.512 \\
(0.738)\end{array}$ & $\begin{array}{c}0.530 \\
(0.761)\end{array}$ & $\begin{array}{c}0.541 \\
(0.779)\end{array}$ \\
\hline $\begin{array}{l}\text { Annual transfer payments received by household } \\
\text { (thousands of Rupees) }\end{array}$ & $\begin{array}{c}1.112 \\
(6.598)\end{array}$ & $\begin{array}{c}1.039 \\
(7.450)\end{array}$ & $\begin{array}{c}1.239 \\
(4.739)\end{array}$ & $\begin{array}{c}1.391 \\
(7.937)\end{array}$ \\
\hline
\end{tabular}


TABLE 1 (contd.)

Sample Means, Standard Deviations in Parentheses

\begin{tabular}{|c|c|c|c|c|}
\hline & $\begin{array}{l}7-19 \\
\text { year olds } \\
(\mathrm{n}=3669)\end{array}$ & $\begin{array}{l}7-12 \\
\text { year olds } \\
(n=2340)\end{array}$ & $\begin{array}{l}13-19 \\
\text { year olds } \\
(\mathrm{n}=1329)\end{array}$ & $\begin{array}{l}\text { Enrolled } \\
7-19 \\
\text { year olds } \\
(\mathrm{n}=2230)\end{array}$ \\
\hline \multicolumn{5}{|l|}{ Village Attributes } \\
\hline Distance to nearest primary school $(\mathrm{km})$ & $\begin{array}{c}0.555 \\
(0.854)\end{array}$ & $\begin{array}{c}0.557 \\
(0.849)\end{array}$ & $\begin{array}{c}0.551 \\
(0.863)\end{array}$ & $\begin{array}{c}0.576 \\
(0.817)\end{array}$ \\
\hline Distance to nearest middle school $(\mathrm{km})$ & $\begin{array}{c}2.653 \\
(2.349)\end{array}$ & $\begin{array}{c}2.729 \\
(2.390)\end{array}$ & $\begin{array}{l}2.518 \\
(2.271)\end{array}$ & $\begin{array}{l}2.525 \\
(2.222)\end{array}$ \\
\hline Distance to nearest secondary school (km) & $\begin{array}{c}4.851 \\
(4.004)\end{array}$ & $\begin{array}{l}4.919 \\
(3.983)\end{array}$ & $\begin{array}{c}4.732 \\
(4.041)\end{array}$ & $\begin{array}{l}4.555 \\
(3.840)\end{array}$ \\
\hline $\begin{array}{l}\text { Village-average annual direct cost of primary } \\
\text { schooling (hundreds of Rupees) }\end{array}$ & $\begin{array}{c}3.729 \\
(2.398)\end{array}$ & $\begin{array}{c}3.664 \\
(2.338)\end{array}$ & $\begin{array}{c}3.844 \\
(2.497)\end{array}$ & $\begin{array}{c}3.684 \\
(2.308)\end{array}$ \\
\hline Village is accessible by a paved road $(=0,1)$ & $\begin{array}{c}0.544 \\
(0.498)\end{array}$ & $\begin{array}{c}0.534 \\
(0.499)\end{array}$ & $\begin{array}{c}0.562 \\
(0.496)\end{array}$ & $\begin{array}{c}0.535 \\
(0.499)\end{array}$ \\
\hline All village agricultural land is irrigated $(=0,1)$ & $\begin{array}{c}0.324 \\
(0.468)\end{array}$ & $\begin{array}{c}0.309 \\
(0.462)\end{array}$ & $\begin{array}{c}0.349 \\
(0.477)\end{array}$ & $\begin{array}{c}0.364 \\
(0.481) \\
\end{array}$ \\
\hline Village is located in the state of Bihar $(=0,1)$ & $\begin{array}{c}0.446 \\
(0.497)\end{array}$ & $\begin{array}{c}0.456 \\
(0.498)\end{array}$ & $\begin{array}{c}0.430 \\
(0.495)\end{array}$ & $\begin{array}{c}0.402 \\
(0.490)\end{array}$ \\
\hline $\begin{array}{l}\text { Village is home to an early childhood } \\
\text { development program }(=0,1)\end{array}$ & $\begin{array}{c}0.377 \\
(0.485)\end{array}$ & $\begin{array}{c}0.363 \\
(0.481)\end{array}$ & $\begin{array}{c}0.401 \\
(0.490)\end{array}$ & $\begin{array}{c}0.404 \\
(0.491)\end{array}$ \\
\hline \multicolumn{5}{|l|}{ Key Variable } \\
\hline $\begin{array}{l}\text { Child or youth attended an early childhood } \\
\text { development program at ages } 0-6\end{array}$ & $\begin{array}{c}0.089 \\
(0.285)\end{array}$ & $\begin{array}{c}0.097 \\
(0.297)\end{array}$ & $\begin{array}{c}0.074 \\
(0.261)\end{array}$ & $\begin{array}{l}0.096 \\
(0.295)\end{array}$ \\
\hline
\end{tabular}


TABLE 2

Determinants of School Enrollment

ML Estimates: prior participation in an early childhood development program considered endogenous $(*, * *, \& * * *$ indicate, respectively, significance at the $10 \%, 5 \%, \& 1 \%$ levels)

\begin{tabular}{|c|c|c|c|}
\hline & $\begin{array}{l}7-19 \\
\text { year olds } \\
(n=3669)\end{array}$ & $\begin{array}{l}7-12 \\
\text { year olds } \\
(n=2340)\end{array}$ & $\begin{array}{l}13-19 \\
\text { year olds } \\
(\mathrm{n}=1329)\end{array}$ \\
\hline \multicolumn{4}{|c|}{ Dependent Variable $=$ Currently Enrolled in School $(=0,1)$} \\
\hline Explanatory Variable & $\begin{array}{l}\text { Coefficient } \\
\text { (S.E.) }\end{array}$ & $\begin{array}{c}\text { Coefficient } \\
\text { (S.E.) }\end{array}$ & $\begin{array}{c}\text { Coefficient } \\
\text { (S.E.) }\end{array}$ \\
\hline Constant & $\begin{array}{c}1.465 * * * \\
(0.166)\end{array}$ & $\begin{array}{c}0.330 \\
(0.210)\end{array}$ & $\begin{array}{c}3.088 * * * \\
(0.407)\end{array}$ \\
\hline \multicolumn{4}{|l|}{ Child/Youth Attributes } \\
\hline Male $(=0,1)$ & $\begin{array}{c}0.585 * * * \\
(0.052)\end{array}$ & $\begin{array}{c}0.537 * * * \\
(0.064)\end{array}$ & $\begin{array}{c}0.746^{* * * *} \\
(0.088)\end{array}$ \\
\hline Age (years) & $\begin{array}{c}-0.105^{* * *} * \\
(0.009)\end{array}$ & $\begin{array}{c}0.023 \\
(0.017)\end{array}$ & $\begin{array}{c}-0.230^{* * * *} \\
(0.026)\end{array}$ \\
\hline \multicolumn{4}{|l|}{ Household Attributes } \\
\hline Family size & $\begin{array}{c}0.051 * * * \\
(0.010)\end{array}$ & $\begin{array}{c}0.043 * * * \\
(0.012)\end{array}$ & $\begin{array}{c}0.057 * * * \\
(0.015)\end{array}$ \\
\hline No. of $0-6$ year old children in household & $\begin{array}{c}-0.115^{* * * *} \\
(0.024)\end{array}$ & $\begin{array}{c}-0.079 * * * \\
(0.029)\end{array}$ & $\begin{array}{c}-0.144 * * * \\
(0.039)\end{array}$ \\
\hline Household head is illiterate $(=0,1)$ & $\begin{array}{c}-0.750 * * * \\
(0.058)\end{array}$ & $\begin{array}{c}-0.791 * * * \\
(0.077)\end{array}$ & $\begin{array}{c}-0.618 * * * \\
(0.086)\end{array}$ \\
\hline Household head is female $(=0,1)$ & $\begin{array}{c}-0.046 \\
(0.124)\end{array}$ & $\begin{array}{c}0.021 \\
(0.147)\end{array}$ & $\begin{array}{c}-0.024 \\
(0.239)\end{array}$ \\
\hline Household's religion is Islam $(=0,1)$ & $\begin{array}{c}-0.173 * * \\
(0.075)\end{array}$ & $\begin{array}{c}-0.062 \\
(0.095)\end{array}$ & $\begin{array}{c}-0.391 * * * \\
(0.129)\end{array}$ \\
\hline Household's landholding (acres) & $\begin{array}{c}0.028 * * * \\
(0.010)\end{array}$ & $\begin{array}{c}0.037 * * * \\
(0.012)\end{array}$ & $\begin{array}{l}0.027 * \\
(0.014)\end{array}$ \\
\hline No. of household non-farm enterprises & $\begin{array}{c}0.025 \\
(0.032)\end{array}$ & $\begin{array}{l}0.0002 \\
(0.040)\end{array}$ & $\begin{array}{c}0.073 \\
(0.052)\end{array}$ \\
\hline $\begin{array}{l}\text { Annual transfer payments received by household } \\
\text { (thousands of Rupees) }\end{array}$ & $\begin{array}{l}0.019 * * * \\
(0.007)\end{array}$ & $\begin{array}{c}0.016 \\
(0.011)\end{array}$ & $\begin{array}{l}0.025 * * * \\
(0.009)\end{array}$ \\
\hline
\end{tabular}


TABLE 2 (contd.)

Determinants of School Enrollment

\begin{tabular}{|l|c|c|c|}
\hline & $\begin{array}{c}7-19 \\
\text { year olds } \\
(\mathrm{n}=3669)\end{array}$ & $\begin{array}{c}7-12 \\
\text { year olds } \\
(\mathrm{n}=2340)\end{array}$ & $\begin{array}{c}13-19 \\
\text { year olds } \\
(\mathrm{n}=1329)\end{array}$ \\
\hline Explanatory Variable & $\begin{array}{c}\text { Coefficient } \\
\text { (S.E.) }\end{array}$ & $\begin{array}{c}\text { Coefficient } \\
\text { (S.E.) }\end{array}$ & $\begin{array}{c}\text { Coefficient } \\
\text { (S.E.) }\end{array}$ \\
\hline Village Attributes & & & \\
\hline Distance to nearest primary school $(\mathrm{km})$ & 0.010 & 0.008 & 0.002 \\
& $(0.029)$ & $(0.037)$ & $(0.049)$ \\
\hline Distance to nearest middle school $(\mathrm{km})$ & $-0.020^{*}$ & $-0.033^{* *}$ & -0.002 \\
& $(0.011)$ & $(0.013)$ & $(0.019)$ \\
\hline Distance to nearest secondary school $(\mathrm{km})$ & $-0.029^{* * *}$ & $-0.025^{* * *}$ & $-0.040^{* * *}$ \\
& $(0.007)$ & $(0.009)$ & $(0.012)$ \\
\hline Village-average annual direct cost of primary & $-0.032^{* * *}$ & $-0.029^{* *}$ & $-0.038^{* *}$ \\
schooling (hundreds of Rupees) & $(0.010)$ & $(0.012)$ & $(0.017)$ \\
\hline Village is accessible by a paved road $(=0,1)$ & 0.027 & 0.029 & 0.045 \\
& $(0.047)$ & $(0.061)$ & $(0.079)$ \\
\hline All village agricultural land is irrigated $(=0,1)$ & $0.185^{* * *}$ & $0.172^{* * *}$ & $0.212^{* *}$ \\
& $(0.052)$ & $(0.067)$ & $(0.085)$ \\
\hline Village is located in the state of Bihar $(=0,1)$ & $-0.252^{* * *}$ & $-0.286^{* * *}$ & -0.080 \\
& $(0.056)$ & $(0.069)$ & $(0.087)$ \\
\hline Key Variable & & & \\
\hline Child or youth attended an early childhood & $1.465^{* * *}$ & $1.270^{* * *}$ & $1.541^{* * *}$ \\
development program at ages 0 - 6 & $(0.166)$ & $(0.274)$ & $(0.411)$ \\
\hline Log-Likelihood & -3106.31 & -1958.38 & -1064.41 \\
\hline
\end{tabular}


TABLE 3

Determinants of Schooling for Age (Grade Progression) of Enrolled 7 - 19 Year Olds ML Estimates: prior participation in an early childhood development program considered endogenous $(*, * *, \& * * *$ indicate, respectively, significance at the $10 \%, 5 \%, \& 1 \%$ levels)

\begin{tabular}{|l|c|}
\hline Dependent Variable $=S A G E=($ [grade enrolled $\div($ age -6$)] \times 100)$ \\
\hline Explanatory Variable & $\begin{array}{c}\text { Coefficient } \\
\text { (S.E.) }\end{array}$ \\
\hline Constant & $142.151^{* * *}$ \\
& $(6.275)$ \\
\hline Child/Youth Attributes & $9.249 * * *$ \\
\hline Male (=0,1) & $(2.392)$ \\
\hline Age (years) & $-5.871^{* * *}$ \\
& $(0.392)$ \\
\hline Household Attributes & 0.550 \\
\hline Family size & $(0.410)$ \\
\hline No. of 0 - 6 year old children in household & -0.919 \\
& $(1.140)$ \\
\hline Household head is illiterate $(=0,1)$ & $-6.964 * * *$ \\
& $(2.424)$ \\
\hline Household head is female $(=0,1)$ & -3.046 \\
& $(6.930)$ \\
\hline Household's religion is Islam (=0,1) & $-9.803 * *$ \\
& $(4.105)$ \\
\hline Household's landholding (acres) & $1.100^{* * *}$ \\
& $(0.203)$ \\
\hline No. of household non-farm enterprises & $-3.097 * *$ \\
& $(1.528)$ \\
\hline Annual transfer payments received by household & 0.010 \\
(thousands of Rupees) & $(0.014)$ \\
\hline
\end{tabular}


TABLE 3 (contd.)

Determinants of Schooling for Age (Grade Progression) of Enrolled 7 - 19 Year Olds

\begin{tabular}{|l|c|}
\hline Explanatory Variable & $\begin{array}{c}\text { Coefficient } \\
\text { (S.E.) }\end{array}$ \\
\hline Village Attributes & -1.906 \\
\hline Distance to nearest primary school $(\mathrm{km})$ & $(1.473)$ \\
\hline Distance to nearest middle school $(\mathrm{km})$ & 0.263 \\
& $(0.579)$ \\
\hline Distance to nearest secondary school $(\mathrm{km})$ & $-0.600^{*}$ \\
& $(0.349)$ \\
\hline Village-average annual direct cost of primary & $0.014^{* * *}$ \\
schooling (hundreds of Rupees) & $(0.005)$ \\
\hline Village is accessible by a paved road (= 0,1) & 3.697 \\
& $(2.350)$ \\
\hline All village agricultural land is irrigated (=0,1) & $5.606^{* *}$ \\
& $(2.553)$ \\
\hline Village is located in the state of Bihar $(=0,1)$ & $4.394^{*}$ \\
& $(2.638)$ \\
\hline Key Variable & $67.360^{* * *}$ \\
\hline Child or youth attended an early childhood & $(4.193)$ \\
\hline development program at ages 0 - 6 & -12431.191 \\
\hline Log-Likelihood &
\end{tabular}

